\title{
EGG BOUND AND VENT PROLAPSE IN CHICKEN - A REVIEW OF TWO CASES
}

\author{
B. Joy* and T. R. Divya \\ Veterinary dispensary, Ayyambuzha, Ernakulam \\ Kerala, India
}

Egg bound is a condition more commonly seen in young birds. The egg binding is a condition in which an egg is lodged in cloaca but not laid Crespo et al. (2003). Obstruction of oviduct or uterus by an egg is a common problem seen mainly in young female birds at the initial stage of laying period.

About six month old two silky hens were presented with the history of swelling at the posterior part of the body since two days. The birds were weak, lethargic, and recumbent and had reduced appetite. On examination a mass was found protruding out from the vent region (Fig. 1). On close examination it was found to be the prolapse of uterus and cloaca with eggs lodged in the uterus in one case (Fig. 2) and egg bound in other case (Fig. 1).

Manual reduction of the condition was done after flushing the site with normal saline solution under local infiltration anesthesia with Lignocaine $2 \%$. In one case the egg was removed easily by gentle manipulation (Fig. 3).

The egg was found to be large and was a normal shelled egg. In the second case where there was prolapse of uterus through cloaca, the egg was found to be lodged inside uterus (Fig. 2). The bird was anesthetized with an intramuscular injection of Ketamine hydrochloride at a very low dose rate the rate of $10 \mathrm{mg} / \mathrm{kg}$. The prolapsed mass was thoroughly washed with luke warm water. It was difficult to reduce the mass with the large egg inside. A tear was noticed on the uterus and the eggs were removed through it (Fig. 4). Two eggs; with one shelled and another shell less were removed. The uterine tear was sutured with chromic catgut size 3/0 in inverted suture pattern (Fig. 5). Reduced the uterus back into the body and thus prolapse was reduced. A purse string suture was put around the cloaca (Fig. 6) and advised the owner to remove the sutures after few hours. Postoperatively antibiotic Enrofloxacin was given at the rate of $10 \mathrm{mg} / \mathrm{kg}$ body weight.

Cloacal prolapse or vent prolapse is a condition where the inner tissues of the cloaca protrude (hang out) from the vent, exposing the intestines, cloaca or uterus. The common causes of egg bound included inflammation of oviduct, partial paralysis of muscles, production of extra large eggs etc. Young pullets laying extra large eggs were also prone to egg binding according to Crespo et al. (2003) which was happened in the present cases. Harrison (1986) described lack of normal muscle tone and lubrication as another causes for egg binding. Oviductal muscle malfunction in Calcium, Selenium, Vitamin E deficiencies, nutritional deficiencies, obesity, stress were described as other causes by Joyner in 1994. All seed diet also led to egg binding because it would be low in calcium as well as other minerals. In this case the dietary imbalance was supposed to be the cause since the owner was giving only grain feeds.

Harcourt (1996) in his studies described the diagnosis, treatment and cause of egg binding in caged birds. Obese and under exercised birds were more prone. Egg binding without torsion or displacement of oviduct was described by Hasholt (1966). In the case of egg binding due to muscular dysfunction rough shelled eggs were reported by him. Samour (2008) described caesarian as an ideal treatment if both egg and hen were conservative and not responding to medical treatment. Oviduct should be incised over the egg and eggs were to be removed. Salpingohysterectomy should be performed in the case of non corrective cases. Oviduct can be sutured with $4 / 0$ absorbable suture material.

*Corresponding e-mail address: drbinijoy@ gmail.com

Copyright (C) 2014 Bangladesh Society for Veterinary Medicine

All rights reserved 0294/2014 


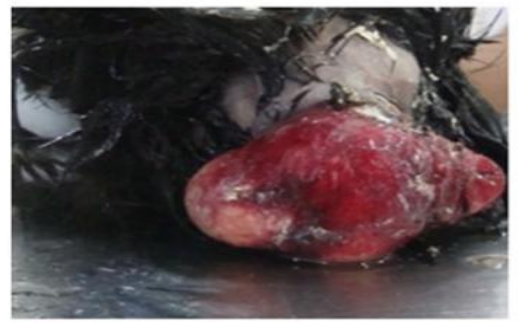

Fig 1. Case 1: Egg bound

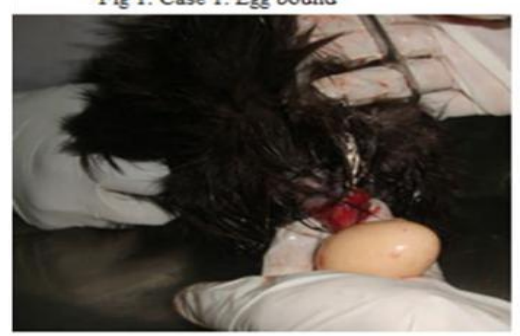

Fig 3. Removal of egg in case 1

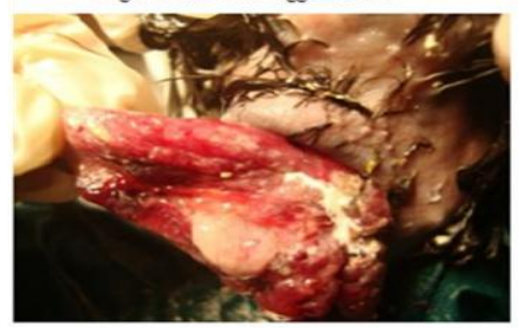

Fig. 5. Uterus after removal of egg

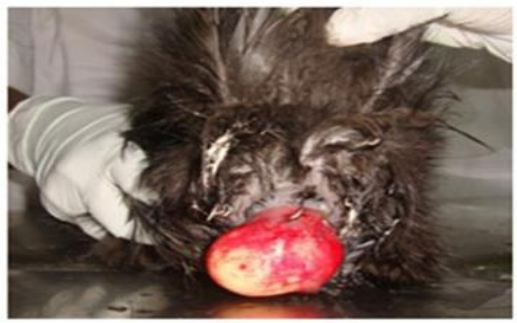

Fig 2. Case 2: Prolapse of uterus

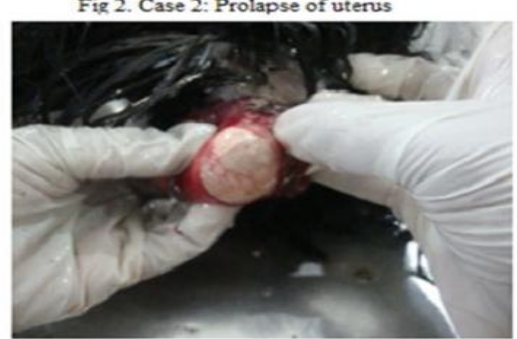

Fig 4. Tear in uterus and egg removal in case 2

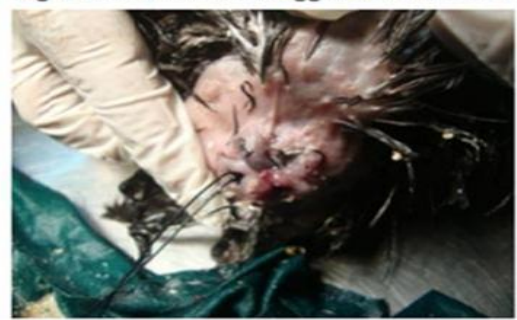

Fig.6. Temporary purse string suture over vent

The injectable anesthesia Ketamine hydrochloride at the rate of $20-50 \mathrm{mg} / \mathrm{kg}$ body weight can be given. In this case, since the bird was weak ketamine was given at the rate of $10 \mathrm{mg} / \mathrm{kg}$ body weight. Harcourt (1996) described hysterectomy and removal of egg, aspiration of contents by hypodermic needle as treatment.

\section{REFERENCES}

1. Crespo R and Shivprasad HL (2003). Developmental, metabolic and other noninfectious disorders. In: Saif YM, ed. Diseases of poultry. (11 $\left.{ }^{\text {th }} \mathrm{edn}\right)$, Iowa state press, Blackwell publishers p. 1231.

2. Harcourt-Brown NH (1996). Torsion and displacement of the oviduct as a cause of egg- binding in four psittacine birds. Journal of Avian Medicine and Surgery 10 (4): 262-267.

3. Harrison GJ (1986). Reproductive medicine. In: Harrison GJ, Harrison LR (eds). Clinical avian medicine and surgery. Philadelphia: WB Saunders, p. 620-623.

4. Hasholt J (1966). Diseases of reproductive organs of pet birds. Journal of Small Animal Practice p. 313-320

5. Joyner KL (1994). Theriogenology. In: Ritchie BW, Harrison GJ, Harrison LR (eds). Avian Medicine, Principles and application. Lake worth Fl: Wingers publishing p. 758-773.

6. Samour J (2008). Avian anesthesia and analgesia, egg binding/ dystocia. Avian medicine, $2^{\text {nd }}$ edn, Mosby Elsevier, Elseviers Ltd, p. 525. 